\title{
THE JURY'S RESPONSE TO BUSINESS AND CORPORATE WRONGDOING
}

\author{
VAlerie P. Hans*
}

I

\section{INTRODUCTION}

Some of the most vociferous criticisms of the jury relate to its performance in cases involving business and corporate wrongdoing. The jury's competence in such cases is assaulted on a variety of fronts. Critics question the jury's factfinding ability in cases with business and corporate parties, and doubt whether lay jurors can understand the often complex and esoteric evidence of business wrongdoing. For example, in a call to replace lay jurors with scientific experts in toxic tort cases, Dan Drazan has lamented that in toxic tort trials, "[l]ay jurors are being asked to digest information that is beyond their reach." " He cites evidence that jurors without the experience and knowledge necessary to evaluate complicated medical and technical evidence simply choose to ignore it. ${ }^{2}$

Others claim that bias and prejudice, rather than evidence, determine jury decisions about businesses and corporations. The presumed biases cut both ways. The generally positive regard in which the public holds business is credited with creating leniency toward business wrongdoing. ${ }^{3}$ Thus, juries are accused of being softer on "suite crime" than on "street crime," and of being reluctant to sanction business wrongdoing with criminal penalties. ${ }^{4}$ In contrast, other critics perceive harsh treatment for businesses in cases that pit corporations against individual litigants. These commentators maintain that civil juries penalize corporations for their ample resources, treating them as deep pockets from which to compensate undeserving victims who have contributed to their own misfortune. ${ }^{5}$ Some writers have even gone so far as to assert that as long as defendants have enough money, their actual negligence is of little concern. For instance, Peter Huber has argued that juries, along with complicit judges, are "committed to running a generous

Copyright $(\mathcal{C} 1989$ by Law and Contemporary Problems

* Associate Professor of Criminal Justice and Psychology, University of Delaware, Newark, Del. Writing was facilitated by National Science Foundation Grant No. SES-8822598. The author wishes to acknowledge the helpful comments of Neil Vidmar, David Ermann, Sam Gaertner, and William Lofquist.

1. Drazan, The Case for Special Juries in Toxic Tort Litigation, 72 Judicature 292, 298 (1989).

2. Id. at 295 .

3. See, e.g., E. Sutherland, White-Collar Crime: The Uncut Version (1983) (originally published in 1949 as White-Collar Crime); Geis, Deterning Corporate Crime, in Corporate Power in AMERICA (R. Nader \& M. Green eds. 1973).

4. See infra notes $82-88$ and accompanying text.

5. See infra notes $101-13$ and accompanying text. 
sort of charity. If the new tort system cannot find a careless defendant after an accident, it will often settle for a merely wealthy one."'6

One need not subscribe to any of these extreme positions, of course, to suspect that the jury may have distinctive responses to business and corporate wrongdoing. Jurors' knowledge of and experiences with business, their understanding of business transactions, and their beliefs about the responsibilities of corporations in contemporary society may all play a role in their determination of liability and damages in specific trials. Yet to date there have been few systematic analyses of how jurors decide cases involving businesses and corporations.

This article begins to develop a comprehensive account of jury decisionmaking in such cases. It starts by showing that suits involving businesses and corporations form an increasing part of the contemporary jury's caseload, and thus deserve systematic scrutiny and investigation. Business presence in the courtroom appears to be increasing in two distinct ways. First, as a result of a long-term normative shift toward greater business responsibility for wrongdoing, more lawsuits are brought against businesses by individuals. Second, there are signs that businesses are using the courts with greater frequency to resolve disputes among themselves. Thus, today's juries are more likely than those of the past to decide both cases in which individuals sue businesses and cases in which businesses sue other businesses.

The issue of jury competence in business cases is best addressed by analyzing existing research on jury decisionmaking. Two key questions about jury competence, reflecting two criticisms of the jury in business cases, will be explored here. First, what are the jury's factfinding abilities in such cases? Are jurors able to understand and evaluate the specialized technical evidence so central to the evaluation of much business wrongdoing? Second, in cases involving individual lawsuits against businesses, are juries biased in their decisionmaking, either for or against business? By reviewing the best evidence available, I aim to provide a current picture of the jury confronted with issues of business and corporate responsibility. I will also discuss unanswered questions that must be addressed by future research.

\section{II}

Cases Involving Businesses and Corporations: An Increasing Part of the Contemporary Jury's Caseload

According to legal scholars, there has been a long-term shift in legal rules and societal norms regarding the responsibility of businesses to compensate individuals who have suffered from business-related injuries. ${ }^{7}$ In nineteenthcentury America, views and practices that held individuals accountable for

6. P. Huber, Liability: The Legal Revolution and Its Consequences 11 (1988).

7. L. Friedman, A History of American Law 467-87, 681-85 (2d ed. 1985); Black, Compensation and the Social Structure of Misfortune, 21 LAW \& Soc'y REv. 563 (1987). For historical and other perspectives on tort liability, see generally R. Rabin, Perspectives on Tort Law (2d ed. 1983). 
their own personal injuries (and absolved businesses and corporations from responsibility) dominated the legal and social terrain. Many bars to recovery from business and corporate groups existed, including the fellow-servant rule, $^{8}$ an expansive assumption of risk doctrine, ${ }^{9}$ and a strict doctrine of contributory negligence, ${ }^{10}$ which prevented recovery if plaintiffs were even slightly negligent themselves.

Ultimately, however, the sheer number and magnitude of business-related personal injuries created attitudinal and legal change. Juries (and softhearted judges) sometimes deviated from the harsh rules precluding recovery for injured citizens, creating incentives for more lawsuits and, eventually, legal transformations. The decline of the fellow-servant rule, ${ }^{11}$ the modification of the doctrines of assumption of risk and contributory negligence, and the introduction of workers' compensation all increased business responsibility for harms. The Progressive Movement and the New Deal in the early part of this century and the civil rights and consumer movements of the 1960's and 1970's, which were accompanied by broad social and attitudinal shifts, contributed to expectations that collective entities such as governments and businesses had the responsibility to compensate for harms. ${ }^{12}$

Legal historian Lawrence Friedman has contended that in contrast to American legal culture in the nineteenth century, when Americans were accustomed to living with calamity and accepted it as part and parcel of life, twentieth-century American legal culture is characterized by a desire for "total justice," the expectation of fair treatment and full compensation for undeserved suffering. ${ }^{13}$ Relying on legal and social changes between the nineteenth and twentieth centuries, Donald Black has documented a gradual movement away from individual responsibility for injury compensation and toward a collective source of responsibility - the organization. ${ }^{14}$ Increased expectations for total justice may have provided the critical catalyst that led to greater responsibility for organizations.

8. The fellow-servant rule generally prohibited recovery from an employer if the injury was caused by a coworker's negligence. See Farwell v. Boston \& Worcester R.R. Corp., 45 Mass. (4 Met.) 49 (1842). See also Friedman \& Ladinsky, Social Change and the Law of Industrial Accidents, 67 Colum. L. REv. 50, 53 (1967).

9. Nineteenth-century workers were considered to have assumed the risks or dangers associated with their jobs, particularly if they were aware of the risks. See Lamson v. American Axe \& Tool Co., 177 Mass. 144, 58 N.E. 585 (1900). See the discussion in R. Epstein, C. Gregory \& H. Kalven, Cases and Materials on Torts 467-81 (4th ed. 1984).

10. A contemporary definition of contributory negligence is provided by the Restatement (Second) of Torts section 463: "Contributory negligence is conduct on the part of the plaintiff which falls below the standard to which he should conform for his own protection, and which is a legally contributing cause co-operating with the negligence of the defendant in bringing about the plaintiff's harm." In the nineteenth century the rule of contributory negligence constituted a complete defense. The rule continues today in a very small number of states. See R. Epstein, C. Gregory \& H. Kalven, supra note 9 , at 439-67.

11. See Friedman \& Ladinsky, supra note 8 .

12. See L. Friedman, Total Justice (1985).

13. Id. See also J. Leiberman, The Litigious Society (1981).

14. Black, supra note 7 . 
By all accounts, the century-long trend toward greater business liability sharply accelerated from the 1960's to the 1980's. Mass tort cases involving product injuries from asbestos, the Dalkon Shield, and toxic substances increased dramatically. ${ }^{15}$ Analyses of legal decisions during this period demonstrate the ascendance of corporate liability principles, although not without some tension between the traditional doctrines of individual responsibility and new theories of group liability. ${ }^{16}$ Changes in product liability laws, including strict liability for defective products ${ }^{17}$ and market share liability, ${ }^{18}$ have increased the likelihood of lawsuits and recoveries against businesses. ${ }^{19}$ Indeed, one scholar has described the movement toward greater civil liability for businesses as one of the most dramatic conceptual revolutions in the Anglo-American legal system. ${ }^{20}$

Several recent cases demonstrate that the list of individual misfortunes for which businesses and corporations must compensate continues to expand. In Cipollone v. Liggett Group, Inc., ${ }^{21}$ a New Jersey jury awarded $\$ 400,000$ to a widower who sued tobacco companies for damages relating to his wife's death from lung cancer allegedly caused by smoking. A San Francisco jury found a blood bank liable for $\$ 750,000$ compensation to the family of a young boy who developed AIDS after a blood transfusion. ${ }^{22}$ And a federal judge issued a pretrial ruling announcing that, under some circumstances, Atlantic City casinos could be held liable for money lost by drunken gamblers. ${ }^{23}$

In addition to changing legal doctrines and public expectations about business liability for individual suffering, there is some evidence that businesses are turning more frequently to the courts to resolve disputes among themselves. Stewart Macaulay's classic study of dispute resolution in the business world, published in 1963, demonstrated that large manufacturers

15. See D. Hensler, W. Felstiner, M. Selvin \& P. Ebener, Asbestos in the Courts: The Challenge of Mass Toxic Torts (1985); D. Hensler, M. Vaiana, J. Kakalik \& M. Peterson, Trends in Tort Litigation: The Story Behind the Statistics (1987); T. Willging, Trends in Asbestos Litigation (1987).

16. Bush, Between Two Worlds: The Shift from Individual to Group Responsibility in the Law of Causation of Injury, 33 UCLA L. REV. 1473 (1986).

17. Greenman v. Yuba Power Prod., Inc., 59 Cal. 2d 57, 377 P.2d 897, 27 Cal. Rptr. 697 (1962); Restatement (SECond) of Torts $\$ 402 A$ (1964).

18. Sindell v. Abbott Laboratories, 26 Cal. 3d 588, 607 P.2d 924, 163 Cal. Rptr. 132, cert. denied, 449 U.S. 912 (1980).

19. G. Eads \& P. Reuter, Designing Safer Products: Corporate Responses to Product Liability Law and Regulation (1983); Priest, The Invention of Enterprise Liability: A Critical History of the Intellectual Foundations of Modern Tort Law, 14 J. LEgal. STud. 461 (1985).

20. Priest, supra note 19. Priest writes that: "Modern tort law generates complicated legal and economic issues-of industrywide apportionment of liability, probabilistic causation, and retroactive liability - that would have appeared bizarre to a lawyer dealing with defective products in the 1950 s whose practice was one of warranty interpretation and routine negligence." Id. at 462 .

21. Cipollone v. Liggett Group. Inc., U.S. District Court, No. 83-2864 (D.N.J. 1988), aff'd in part, rev'd in part, and remanded, 893 F.2d 541 (3d Cir. 1990).

22. Osborn v. Irwin Memorial Blood Bank, 891-642 (San Francisco Super. Ct.), Nat'l. L.J., Dec. 19,1988 , at 6

23. The judge relied on New Jersey's dram-shop laws holding taverns responsible for damages caused by drunken customers to rule that "a casino has a duty to refrain from knowingly permitting an invitee to gamble where that patron is obviously and visibly incoxicated ... ." Smith \& Sorra, Casinos May Be Held Liable For Drunken Patrons' Losses, Wall St. J., June 23, 1989, at B1, col. 3. 
went to great lengths to avoid the courts. ${ }^{24}$ Yet Marc Galanter has reported data indicating significant increases over the last two decades of federal court filings in a variety of forms of commercial litigation. ${ }^{25}$ Most striking was the change in contract-dispute filings, which increased 258 percent from 1960 to 1986, compared to a 114 percent increase in tort filings. ${ }^{26}$ Other types of cases connected to business disputes, such as those involving intellectual property and bankruptcy, also showed significant increases over that period. ${ }^{27}$

Not surprisingly, more of these cases are being decided by juries. Mark Peterson analyzed state and federal jury trials in Cook County, Illinois, and San Francisco, California, from 1960 to $1984 .{ }^{28}$ Jury trials in business/contract cases increased notably over the two decades in both jurisdictions. ${ }^{29}$ Indeed, in the 1980's, a quarter of all San Francisco jury trials concerned a business or contract dispute. ${ }^{30}$ Noting that San Francisco County and Santa Clara County, home of Silicon Valley, were the two California counties with the highest rates of business/contract dispute jury trials, Peterson attributed this fact to the substantial commercial activity in both counties. ${ }^{31}$ Yet even in jurisdictions without such concentrated business enterprises, the number of jury trials pertaining to business was still significant. Business/contract disputes accounted for 14 percent of all civil jury trials in the state of California in the 1980's. ${ }^{32}$ If the percentage of business/contract jury trials (14 percent) is combined with two other frequent types of civil trials involving businesses-product liability trials (12 percent) and work injury trials ( 8 percent) - it is evident that at least a third (34 percent) of California civil jury trials in the early 1980's involved issues of business or corporate responsibility. In Cook County, one of every five cases fell into one of these three categories. ${ }^{33}$ Thus, across jurisdictions, a substantial percentage of civil jury trials centers on questions involving business and corporate responsibility.

24. Macaulay, Non-Contractual Relations in Business: A Preliminary Study, 28 AM. Soc. REv. 55 (1963).

25. Galanter, The Life and Times of the Big Six; or, The Federal Courts Since the Good Old Days, 1988 Wis. L. Rev. 921, 925, Table 1.

26. Id. at 942 .

27. Galanter speculates on the causes of such changes, including the rise in corporate mergers and acquisitions, the growth of franchises, subsidiaries, and other complexities in relations among businesses, greater competition in international markets, and the increase in lawyers. Id. at 942-46, 953-54. For further elaboration see M. Galanter \& J. Rogers, The Transformation of American Business Disputing? Some Preliminary Observations (June 1988) (unpublished paper delivered at the 1988 Meeting of the Law and Society Ass'n).

28. M. Peterson, Civil Juries in the 1980s: Trends in Jury Trials and Verdicts in California and Cook County, Illinois (1987).

29. Id. at 11, Table 2.3. In San Francisco from 1960-1964, there were 41 business/contract jury trials; the number jumped to 152 during the 1980-1984 time period. Similarly, in Cook County, there were just 17 business/contract jury trials during 1960-1964. Two decades later the number of business/contract jury trials was 286 .

30. Id. at 14 .

31. Id. at 41 .

32. Id. at 40 , Table 4.2 .

33. Id. 
The available aggregate statistics demonstrating an increased business presence in the courts do not reveal the range and diversity of the types of cases and issues confronting juries. It is clearly too simplistic to assume that juries take a unidimensional approach to all business cases. Consider, for example, the dramatically different concerns likely to be raised when juries evaluate product liability matters, trademark infringements, antitrust violations, and stockholder class-action lawsuits. In particular, cases in which individuals sue businesses and in which businesses sue each other are likely to diverge. A comprehensive theory of jury decisionmaking in business cases cannot be developed without more precise and detailed information about the use of the courts by businesses. A large-scale research program examining the changes in business disputes is now under way at the University of Wisconsin and should help to provide a clearer picture of what kinds of issues jurors are asked to decide in such cases. ${ }^{34}$ Despite our current dearth of detailed knowledge, historical and recent trends clearly show that the contemporary jury is more likely than ever before to hear cases with businesses and corporations as parties. ${ }^{35}$

\section{III}

The Jury's Factfinding Abilities in Cases of Business and Corporate WrongdoIng

Because a significant proportion of the jury's work involves the evaluation of business liability, it is important to determine jurors' competence in this area. Are business and corporate cases so far outside the typical juror's experience that juries regularly make factfinding errors? A comprehensive answer to this question would require thorough analyses of jury decisionmaking across different kinds of cases, because some types of cases pose greater challenges to juror comprehension than others. For example, knowledge of the business world might be critical to understanding key issues in certain disputes between businesses (such as antitrust or contract cases) but would be less germane to grasping central issues in disputes between individuals and businesses (such as product liability or worker recovery suits). We are not yet close to a full understanding of jury competence in business cases, but a review of past research on jury decisionmaking can provide some pertinent insights.

34. M. Galanter \& J. Rogers, supra note 27; M. Galanter, S. Macaulay, T. Palay \& J. Rogers, The Transformation of American Business Disputing (Jan. 1989) (unpublished manuscript, Disputes Processing Research Program, University of Wisconsin).

35. In some jurisdictions, businesses have long been a frequent target of lawsuits. Stephen Daniels has indicated that the two most frequently sued entities in Springfield, Illinois, at the turn of the century were coal-mining companies and railroads. According to his research, plaintiffs did not win very often, but they nevertheless sued the two deepest pockets in the community with some regularity. Personal communication with S. Daniels (Oct. 29, 1988). Historical research analyzing the frequency and outcomes of court cases over time would be necessary to determine whether plaintiffs in this community are more likely to bring suit or to prevail today, a pattern that would be consistent with the argument advanced here. 
Before turning to the general body of research on jury decisionmaking, it is worth noting that specific concerns have been raised about jury competence in extremely complex civil litigation. There has been extensive scholarly debate about whether there is a complexity exception to the seventh amendment right to a civil jury. Are there civil cases so difficult for juries to understand that the due process clause of the fifth amendment requires an alternative tribunal? The circuits are split on the issue, with the Third Circuit finding a complexity exception ${ }^{36}$ and the Ninth Circuit denying such an exception. ${ }^{37}$ The extensive review of this controversy by other scholars ${ }^{38}$ will not be reviewed here, except to note two points important to our discussion. First, many of the most complex trials confronting the justice system involve businesses and corporations. ${ }^{39}$ Indeed, the Third and Ninth Circuit cases that led to contrary appellate decisions about a seventh amendment complexity exception both involved massive business enterprises. The second point is that empirical evidence bearing on jurors' factfinding abilities in complex cases is quite sparse. ${ }^{40}$ Much of the debate over jurors' limitations is based on speculation rather than evidence.

\section{A. General Findings About Jury Competence}

The evaluation of the jury's competence in factfinding has been a central interest of jury researchers. ${ }^{41}$ Although the vast majority of studies of jury competence have examined criminal trials, the work still furnishes a useful background for our discussion of jury competence in trials involving businesses.

Researchers in the University of Chicago Law School's Jury Project in the 1950 's were among the first to investigate empirically the jury's factfinding competence. Researchers Harry Kalven and Hans Zeisel ${ }^{42}$ compared actual verdicts reached by juries with hypothetical verdicts rendered by judges

36. Zenith Radio Corp. v. Matsushita Elec. Indus. Co., 478 F. Supp. 889 (E.D. Pa. 1979), vacated, 631 F.2d 1069 (3d Cir. 1980).

37. In re U.S. Fin. Sec. Litig., 75 F.R.D. 702 (S.D. Cal. 1977), rev'd, 609 F.2d 411 (9th Cir. 1979), cert. denied, 446 U.S. 929 (1980).

38. See, e.g., Arnold, A Historical Inquiry into the Right to Trial by Jury in Complex Civil Litigation, 128 U. PA. L. Rev. 829 (1980); Campbell \& Le Poidevin, Complex Cases and Jury Trials: A Reply to Professor Arnold, 128 U. PA. L. Rev. 965 (1980); Kirst, The Jury's Historic Domain in Complex Cases, 58 Wash. L. Rev. I (1982); Lempert, Civil Juries and Complex Cases: Let's Not Rush to Judgment, 80 MiCH. L. Rev. 68 (1981); Oakes, The Right to Strike the Jury Trial Demand in Complex Litigation, 34 U. MIAMI L. Rev. 243 (1980); Sperlich, The Case for Preserving Trial by Jury in Complex Civil Litigation, 65 Judicature 394 (1982).

39. J. Cecil, E. Lind \& G. Bermant, Jury Service in Lengthy Civil Trials 12, Table 1 (1987).

40. "Although various views have been expressed about the practical abilities of jurors, there has been little substantive research done on the subject." In re U.S. Fin. Sec. Litig., 609 F.2d at 430. "Neither the social science community nor the legal profession has furnished the courts with the information needed for empirically grounded judgments about the capacity of juries to rationally decide the issues posed by complex civil suits." Lempert, supra note 38, at 70-71.

41. J. Guinther, The Jury in America (1988); V. Hans \& N. Vidmar, Judging the Jury 113-29 (1986); S. Kassin \& L. Wrightsman, The american Jury on Trial 119-39 (1988); R. MacCoun, Getting Inside the Black Box: Toward a Better Understanding of Civil Jury Behavior (1987).

42. H. Kalven \& H. Zeisel, The American Jury (1966); Kalven, The Dignity of the Civil Jury, 50 VA. L. REV. 1055 (1964). 
presiding over the same cases. In both criminal and civil trials, there was a high rate of judge-jury agreement: Judges agreed with juries 78 percent of the time. ${ }^{43}$ When disagreement occurred in criminal cases, juries tended to favor the defendant's acquittal more than judges did, ${ }^{44}$ but in civil cases the disagreements were evenly balanced between plaintiff and defendant verdicts. ${ }^{45}$

Kalven and Zeisel addressed the issue of jury competence by analyzing the characteristics of criminal cases in which judge and jury disagreed. Judges rated the trial evidence as easy, somewhat difficult, or very difficult to comprehend. The researchers reasoned that if juries differed from judges because juries fundamentally misunderstood the evidence, then the disagreement rate would be higher in the more difficult cases. No such pattern was found. Judges and juries were just as likely to disagree in the cases with easy and difficult evidence, ${ }^{46}$ leading Kalven and Zeisel to conclude that the jury generally does not misunderstand the evidence. Few, if any, of the criminal cases in the Kalven and Zeisel study appeared to involve businesses or corporations. ${ }^{47}$

Two other studies of jury competence in criminal trials used regression techniques to determine the contribution of trial evidence, case characteristics, and extralegal variables to juror judgments or verdicts. ${ }^{48}$ Both studies revealed that reactions to criminal cases were strongly grounded in legally relevant evidence, suggesting that the jury performed in a generally competent manner. In contrast, however, Baldwin and McConville concluded from their study of British juries that a significant number of jury verdicts, particularly acquittals, were questionable. ${ }^{49}$

Supporters of the jury have frequently noted that an important enhancement of jury competence is the group deliberation, where jurors have the opportunity to discuss and debate the evidence and correct one another's factual misunderstandings. ${ }^{50}$ Empirical evidence from mock-jury studies confirms that the group nature of the deliberation can provide protection against individual factfinding errors. In their study of mock juries in a criminal trial, Reid Hastie, Steven Penrod, and Nancy Pennington found that during deliberation, jurors tended to correct one another's factual misunderstandings. ${ }^{51}$ In a separate study using the same mock-trial evidence,

43. H. Kalven \& H. Zeisel, supra note 42, at 58, Table 12 (criminal trials); id. at 63, Table 16 (civil trials).

44. Id. at 58, Table 12 .

45. Id. at 63 , Table 16 .

46. Id. at 157 , Table 50 .

47. Id. at 66-81. A companion volume discussing the results of some 4000 civil jury trials, which presumably would have included a number of cases involving businesses and corporations, was promised, id. at $63 \mathrm{n} .1 \mathrm{l}$, but never materialized.

48. Myers, Rule Departures and Making Law: Juries and Their Verdicts, 13 LAW \& Soc'y REv. 781 (1979); Visher, Jury Decision Making: The Importance of Evidence, 11 Law \& Hum. BeHav. 1 (1987).

49. J. Baldwin \& M. McConville, Jury Trials (1979). But see V. Hans \& N. Vidmar, supra note 41, at 118-20 for a fuller discussion of Baldwin and McConville's work.

50. V. HANS \& N. VIDMAR, supra note 41 , at 120.

51. R. Hastie, S. Penrod \& N. Pennington, Inside the Jury 88-89 (1983). 
Phoebe Ellsworth also discovered that simulated jurors were likely to correct one another on factual matters. ${ }^{52}$ In the study by Hastie and his colleagues, individual jurors' memories of facts and judicial instructions were not substantial; however, when their recollections were pooled, the groups remembered 90 percent of the evidence and 80 percent of the judge's instructions. ${ }^{53}$ The collective wisdom of the jury can thus counteract individual memory failings. The research all indicates that, for garden-variety criminal trials, the jury is generally a competent factfinder.

In contrast, jury researchers are nearly unanimous in giving the jury poor marks for its understanding of legal instructions. ${ }^{54}$ The jury's difficulties have been attributed to the characteristically complex language in which legal instructions are written and the circumstances under which they are presented. Jurors' comprehension of legal instructions may be improved by such changes as rewriting, ${ }^{55}$ instructing jurors at both the beginning and the end of the trial, ${ }^{56}$ and incorporating other procedural modifications. ${ }^{57}$ However, deliberating jurors do not appear to be as able to police themselves when they make legal misstatements as they are when making factual misstatements. ${ }^{58}$ The conclusion emerging from these studies of jury decisionmaking is that the jury is generally a competent factfinder, although it has difficulty understanding and applying legal instructions.

Although most research on the jury has examined the criminal jury, the majority of cases involving businesses occur in the civil context. The determination of liability and damages rather than criminal responsibility, as well as other differences between civil and criminal procedure, could well affect jury decisionmaking competence. Work on civil jury decisionmaking is increasing and promises to fill some of the gaps in our knowledge. ${ }^{59}$ Interestingly, however, lay persons often blur the distinctions between the

52. Ellsworth, Are Twelve Heads Better Than One?, Law \& Contemp. Probs., Autumn 1989, at 205.

53. R. Hastie, S. Penrod \& N. Pennington, supra note 51, at 81.

54. For general discussions, see V. Hans \& N. VIDmar, supra note 41, at 120-27; Elwork \& Sales, Jury Instructions, in The Psychology of Evidence and Trial Procedure 280 (S. Kassin \& L. Wrightsman eds. 1985). Recent empirical demonstrations of jurors' difficulty with legal instructions may be found in V. Smith, The Psychological and Legal Implications of Pre-Trial Instruction in the Law (1987) (unpublished doctoral dissertation, Stanford University); E. Wiggins, Procedural Innovations to Enhance Juror Comprehension in Complex Litigation (1987) (unpublished doctoral dissertation, The Johns Hopkins University).

55. A. Elwork, B. Sales \& J. Alfini, Making Jury Instructions Understandable (1982); Severance \& Loftus, Improving the Ability of Jurors to Comprehend and Apply Criminal Jury Instructions, 17 LAW \& Soc'Y Rev. 153 (1982).

56. V. Smith, supra note 54.

57. Heuer \& Penrod, Increasing Jurors' Participation in Trials: A Field Experiment with Jury Notetaking and Question Asking, 12 LaW \& Hum. Behav. 231 (1988). Heuer and Penrod found no clear evidence that juror notetaking and question asking increased juror performance on a multiple-choice test of legal issues, but they discovered a number of other benefits from the two procedures.

58. Ellsworth, supra note 52 at Parts IV. A, B.

59. J. Guinther, supra note 41; R. MACCoun, supra note 41; Bordens \& Horowitz, Mass Tort Civil Litigation: The Impact of Procedural Changes on Jury Decisions, 73 JudiCaTure 22 (1989); Horowitz \& Bordens, The Effects of Outlier Presence, Plaintiff Population Size, and Aggregation of Plaintiffs on Simulated Civil Jury Decisions, 12 Law \& Hum. Behav. 209 (1988). 
criminal and civil justice systems, suggesting that the approaches juries take to deciding civil and criminal responsibility may overlap substantially. ${ }^{60}$

\section{B. Distinctive Features of Business and Corporate Cases That May Affect Jury Competence}

Now let us turn more directly to the question of jury competence in business and corporate cases. There are a number of reasons why jury factfinding might differ in cases involving questions of business and corporate wrongdoing. Perhaps most centrally, these cases involve a different type of party - a fact that has some implications for the jury's enterprise. It may be a more straightforward task for individual jurors to conceptualize and apply a reasonable person standard than a reasonable corporation standard. Knowledge of prevailing norms and standards of care in the business world could be essential to understanding and assessing whether companies were negligent in specific instances.

Complicating the picture is the thorny problem of evaluating group responsibility for a harm. Consider the case of the Ford Motor Company's criminal trial on charges of reckless homicide for the deaths of three teenagers whose Ford Pinto gas tank exploded after a rear-end crash. The jury acquitted the automobile company in the criminal trial. After the acquittal, commentators noted the complications in trying to establish criminal intent and impose criminal liability on a corporate entity when those issues traditionally have focused on individuals. ${ }^{61}$

Other factors may also affect jury decisionmaking in business cases. The nature of the evidence may differ substantially between business and nonbusiness cases. For example, both the quantity and the complexity of scientific and economic data in business cases are likely to be much greater than in criminal or ordinary tort cases. Finally, people may have biases and preconceptions about businesses and corporations that affect their decisionmaking.

\section{Empirical Research on Jury Factfinding in Business Cases}

1. Case Studies. Two recent case studies of jury performance in complex civil trials involving corporations provide some interesting though incomplete information about how jurors approach these cases. One was an antitrust case involving a dispute among businesses, while the other concerned a product liability trial in which individual plaintiffs sued companies. The study of the antitrust trial indicates both strengths and weaknesses of jury decisionmaking. Austin interviewed members of two civil juries that heard the same

60. O'Barr and Conley discovered that the plaintiffs they interviewed in small claims court often confused criminal and civil trial concepts. O'Barr \& Conley, Lay Expectations of the Civil Justice System, 22 LAW \& Soc'y Rev. 137 (1988).

61. F. Cullen, W. Mankestad \& G. Canender, Corporate Crime Under Attack (1987); Swigert \& Farrell, Corporate Homicide: Definitional Processes in the Creation of Deviance, 15 LAw \& Soc'Y REV. 161 (1980-1981). 
complicated antitrust case. ${ }^{62}$ The second jury was assembled after the first jury had been unable to reach a verdict. In discussing and evaluating the jurors' understanding of the case, Austin distinguished between their ability to comprehend what he labeled "primary" facts (historical facts, technological facts, and behavioral facts) and "economic" facts (judgments of economic effects, often involving market performance and statistical predictions). Austin concluded that the jurors he interviewed had a good grasp of the primary facts in the antitrust case, but they had difficulty understanding economic facts. This conclusion is consistent with other findings indicating that the American public is deficient in understanding basic economic principles. ${ }^{63}$ More research should examine this potential problem across a range of cases, but for now the problem raises an immediate concern about juries in business cases, many of which include financial and economic data.

In a second case study, Rand researchers Molly Selvin and Larry Picus studied jurors in a complex trial involving liability for injuries from asbestos. ${ }^{64}$ The case involved four plaintiffs who had been exposed to different amounts of asbestos and who had varying degrees of physical infirmity. The plaintiffs' doctors argued that all four suffered from asbestosis, but the defense countered with two medical experts who asserted that three of the four did not have asbestosis. The jury found for the plaintiffs.

Selvin and Picus interviewed jurors after the trial to assess their understanding of the causal arguments regarding asbestosis as well as their approach to decisions about liability and damages. They concluded that the jurors seriously misunderstood the development of asbestosis. Jurors tended to believe that everyone exposed to asbestos would fall victim to the disease and that all the plaintiffs would ultimately become as ill as the most seriously injured plaintiff in the lawsuit. In fact, asbestosis can have a range of effects.

Some critics might maintain that the jury's failure to understand the progress of asbestosis constitutes evidence of the jury's inherent incompetence in evaluating complex technical matters. However, by examining the presentation of the medical testimony and jurors' inferences from the testimony, one can observe that the adversary nature of the presentation of evidence led directly to the jury's factual misunderstanding. ${ }^{65}$ The plaintiffs' expert evidence suggested to jurors that asbestosis always reached the same dreadful terminal phase, apparently leading them to conclude that all four of the plaintiffs would be as severely injured as the

62. A. Austin, Complex litigation Confronts the Jury System: A Case Study (1984).

63. Carmody, Many Students Fail Quiz on Basic Economics, N.Y. Times, Dec. 29, 1988, at A1, col. 2. The article reported the results of a study sponsored by the Joint Council on Economic Education showing that more than half of 8205 high school students given a multiple-choice test could not define such terms as inflation, profit, and government budget deficit.

64. M. Selvin \& L. Picus, The Debate over Jury Performance: Observations from a Recent Asbestos Case (1987).

65. "Because neither the plaintiffs' nor the defendants' attorneys had provided the jury with much information on the variable nature of asbestosis, once the jurors decided each plaintiff did indeed have asbestosis, they concluded that each would become as sick as [the sickest plaintiff]." Id. at 41 . 
sickest one. The defense made an equally self-interested tactical decision to deny completely that three of the four plaintiffs had asbestosis. We can surmise that it was not perceived to be in the interest of either adversary to present jurors with information about the true range and variability of the disease. The joint strategies of plaintiff and defendant thus left the jury in the dark.

The Rand study is but one example of a more general predicament that is apt to affect both judges and juries alike. The adversarial presentation of complex technical evidence through expert witnesses is likely to lead to evaluation problems for the decisionmaker. Part of the jury's unique strength as a factfinder is that jurors rely on a range of insights and background experiences in evaluating trial evidence. Because technical evidence is frequently outside the direct experience of the jurors, they are less able to use their own knowledge and experience as checks on the gaps and exaggerations in evidence presented within the adversary format. In many cases, technical evidence may not be effectively corrected by cross-examination or by the presentation of an opposing expert. ${ }^{66}$ In judging jury competence, one needs to recognize that often the jury will be evaluating evidence under less than optimal conditions. Yet one cannot forget that the major alternative to the jury-the judge-is also likely to be unschooled in techniques of evaluating complex technical evidence. ${ }^{67}$ Further analyses may show that factfinding errors are not necessarily the result of weaknesses intrinsic to judge or jury but rather potentially correctable problems in the presentation of technical and complex evidence.

While these case studies add to our understanding of the way individual juries perform and point to specific topics in which juries may need guidance, it is difficult to know the extent to which they have identified problems common to all such jury trials or specific difficulties that arose in the individual trials. Jury performance in specific trials can be affected by the manner in which complex information is presented, the communication abilities of the experts, tactical decisions about evidence inclusion, and so on. Thus, it is useful to examine performance issues across a wider range of trials.

2. More General Research. Systematic study of jury decisionmaking in business and corporate cases is just beginning. ${ }^{68}$ However, some insights into

66. See, e.g., The Evolving Role of Statistical Assessments as Evidence in the Courts 15664 (S. Fienberg ed. 1989) [hereinafter Evolving Role].

67. Vidmar, Assessing the Impact of Statistical Evidence, A Social Science Perspective, in Evolvinc Role, id. at 279-319 (reviewing additional data showing that judges are not immune from factual misunderstandings). Furthermore, the factfinding situation may be more demanding in judge-only trials. A Federal Judicial Center survey of attorneys and judges in lengthy federal trials discovered that lawyers often worked hard to present complex evidence in streamlined and more coherent form for jury trials. Attorneys rarely engaged in the same kind of efforts in judge-only trials. G. BERMANT, J. Cecil, A. Chaset, E. Lind \& P. Lombard, Protracted Civil Trials: Views from the Bench and the Bar (1981) [hereinafter Protracted Civil Trials].

68. The National Science Foundation funded two such projects in 1989. See V. Hans, Public Views of Corporate Responsibility for Wrongdoing (1989); R. MacCoun, Understanding Civil Jury Verdicts in Personal Injury Cases (1989). See also Bordens \& Horowitz, supra note 59; 
possible areas of strength and vulnerability of juries may be derived from ongoing research programs on how jurors react to specific types of evidence commonly found in business cases. By their nature, business and corporate trials are likely to include medical, scientific, statistical, economic, or financial testimony. There has been considerable concern that jurors give undue weight to scientific evidence because it possesses an aura of certainty. Another fear is that jurors, failing to understand scientific evidence, simply ignore it. ${ }^{69}$

Converging with the conclusions of the Austin case study, recent research suggests that statistical and economic data present particular difficulties for lay factfinders. William Thompson's line of experimental research indicates that probability evidence is likely to be misinterpreted by those who are untrained in mathematics and statistics. ${ }^{70}$ In experimental studies in which mock jurors were presented with scientific and quantitative evidence, Jane Goodman found that, contrary to the beliefs of critics of jury competence, the presentation of scientific evidence was not ignored, nor did it overwhelm other factors in jurors' judgments. ${ }^{71}$ She did discover, however, errors in comprehension of quantitative evidence. New work on how jurors assess damages demonstrates substantial variability ${ }^{72}$ and some evaluation problems. ${ }^{73}$ Indeed, the Fienberg volume concluded that statistical evidence presents demanding challenges to both judges and juries. ${ }^{\mathbf{7 4}}$

Although simulation studies show that jurors may sometimes misunderstand technical evidence, the overall impact of comprehension errors on the part of individual jurors may prove to be modest. Full and competent adversarial examination of disputed technical issues, visual aids, and group deliberation may counteract individual errors so that the group decision is a competent one. ${ }^{75}$ In a Federal Judicial Center interview study with judges and lawyers who participated in protracted and often difficult trials, the judges and lawyers favorably noted the diligence of juries in their cases and were generally supportive of the juries' decisionmaking. ${ }^{76}$ The

Diamond, Blindfolding the Jury, Law \& Contemp. Probs., Autumn 1989, at 247; Horowitz \& Bordens, supra note 59 .

69. See Vidmar, supra note 67.

70. Thompson, Are Juries Competent to Evaluate Statistical Evidence?, Law \& Contemp. Probs., Autumn 1989, at 9. Of course, this limitation is not exclusively the province of jurors. Judges, too, make errors in interpreting probability evidence.

71. J. Goodman, Jurors' Comprehension of Scientific Evidence (June 1988) (unpublished paper delivered at the 1988 Meeting of the Law \&c Society Ass'n).

72. See Greene, On Juries and Damage Awards: The Process of Decisionmaking, Law \& ConTEMP. Probs., Autumn 1989, at 225.

73. Id. at Part IV.B.3 (discussing the research that she, Goodman, and Loftus have conducted on how jurors determine damages).

74. Evolving Role, supra note 66.

75. One interesting question about the potentially corrective effect of group deliberation is whether errors in comprehension of scientific facts are corrected during deliberation by other jurors. Several researchers have discovered that jurors tend to correct one another's factual but not legal misstatements. See supra text accompanying notes 50-58. When it comes to being corrected by other jurors, do technical matters resemble factual or legal matters?

76. Protracted Civil Trials, supra note 67, at 52. 
judges and lawyers were asked whether their trials had contained difficult issues. The report concludes: "Almost without exception, respondents who acknowledged the existence of difficult issues in their jury trials also mentioned explicitly that the jury had made the correct decision or that the jury had no difficulty applying the legal standards to the facts." 77

3. Jury Selection. Jury selection and composition constitute another important factor affecting the competence of jury decisionmaking in business trials. Many lengthy trials involve businesses and corporations. Examining who serves on juries in complex and lengthy trials, one observes a not altogether surprising phenomenon. In a study conducted by the Federal Judicial Center, jurors in very lengthy federal trials were less likely to be college educated and more likely to be unemployed than jurors in shorter trials. ${ }^{78}$ One source of this pattern may be that employed jurors are more likely to request excuses. As a lawyer who participated in one protracted trial quipped, "No one who earns a decent living could afford to be on this jury."79

A second possibility is that prospective jurors with experience and knowledge of the business world may be disproportionately excluded through lawyers' peremptory challenges. Adversarial attorneys desire favorable jurors, and if business knowledge could interfere with acceptance of their theory of the case, they may use peremptory challenges to try to obtain a less informed jury. Consider the results of pretrial mock-jury research in the "Chevymobile" engine-switch case. ${ }^{80}$ Plaintiffs argued that General Motors breached its warranty when the company, without informing consumers, installed a nonstandard engine in some car models. General Motors countered that the engines were comparable products and that interchanging parts was standard practice in the auto industry. During a pretrial jury simulation sponsored by the plaintiffs, one mock juror who was an employee of an import company argued that interchanging component parts was common in her business; her mock jury decided in favor of the defendant. The plaintiffs' attorneys were thus forewarned to challenge jurors with similar occupational backgrounds. Through both excuses and challenges, prospective jurors who are sophisticated about business may be less likely to sit as jurors in business cases.

\section{Summary}

This review of issues and evidence pertaining to jury factfinding in business/corporate trials highlights several areas in which more research and study are needed. Prior research on jury decisionmaking provides us with some confidence that juries generally render competent verdicts. However,

77. Id. at 26.

78. J. Cecil, E. Lind \& G. Bermant, supra note 39, at 19, Table 4. Jurors in longer trials were also more likely to be women and to be unmarried.

79. Protracted Civil Trials, supra note 67 , at 53

80. Kassin, Mock Jury Trials, 7 TRIAL DiPL. J. 26 (1984). 
there are some areas where juries may need special assistance. Jurors with little or no business experience, presented with specialized bodies of scientific and statistical evidence, may be particularly vulnerable to the limitations of the adversarial system. Tactical decisions to present a restricted amount of evidence, coupled with the mandated passive role of the decisionmaker, can lead to distorted pictures of reality for juries.

\section{IV}

\section{JURY BIASES}

In addition to having concerns about factfinding competence, some observers are convinced that jury decisions in business and corporate cases are infected by prejudice-either for or against the companies. Most allegations of bias pertain to trials in which corporations are pitted against individuals, rather than trials involving disputes between businesses. Perhaps the most popular assertion of bias pertains to personal injury cases, when individual plaintiffs sue corporations for compensation for business-related injuries. Juries are alleged to follow a "deep pockets" principle in such cases, and to award plaintiffs who sue corporations large sums of money because the jurors presume that the wealthy corporations can afford it. ${ }^{81}$ Other observers assert in contrast that the public is so enamored of business that it is excessively tolerant of corporate wrongdoing, permitting businesses to engage in actions for which individuals would be punished. ${ }^{82}$

Indeed, beliefs about the differential treatment of corporations are so widespread that a number of jurisdictions have developed pattern jury instructions that caution jurors that corporations should be treated just the same as individuals. The Modern Federal Jury Instructions version reads as follows:

In this case, [one of] the plaintiff(s) (or defendant(s)) is a corporation. The mere fact that one of the parties is a corporation does not mean it is entitled to any lesser consideration by you. All persons are equal

81. In an article about the extensive litigation surrounding the Exxon-Valdez oil spill that caused massive environmental damage in Alaska, one legal consultant maintained: "There are a lot of people out there who are looking to rape a deep pocket like Exxon . . . Companies like Exxon have to be tough on litigation to send a message to the plaintiffs' bar that, 'We're not going to mess around." Blum, Exxon After the Spill, Nat'l. L.J., July 3, 1989, at 1, 38. It is notable that the consultant equated the filing of a personal injury lawsuit with rape, one of the most heinous of criminal acts, and one that is experienced as deeply violative of a person's integrity.

82. Opponents of the Department of Justice's settlement of E.F. Hutton's "check-kiting" charges compared Hutton's treatment to that of hypothetical similarly guilty individuals. The Justice Department imposed only civil financial penalties on Hutton for a scheme in which checks were shuffled among banks, creating overdrafts of up to $\$ 10$ billion. Senator Joseph Biden, D. Del., criticized the absence of criminal penalties, noting that "I can name eight of my clients, when I was a lawyer, who went to jail for check-kiting .... I'm supposed to go around talking about jailing people for drunk driving, and you can go out and steal a million dollars and it's, hey, see you around the club." Welch, Hearing Feels Heat From E. F. Hulton Decision, The Morning News (Wilmington, Del.), May 16, 1985, at Al4. 
before the law, and corporations, big or small, are entitled to the same fair consideration as you would give any other individual party. ${ }^{\mathbf{8 3}}$

General attitudes toward business and corporations may lead jurors to perceive and treat corporate wrongdoing distinctively. Just as sympathy and prejudice can be found in the jury box when individuals stand trial, ${ }^{\mathbf{8 4}}$ stereotypes of corporations could affect perceptions of corporate wrongdoing. Anti-business attitudes may create harshness, whereas probusiness sentiments may lead to more lenient evaluation and treatment. Extensive personal experience with business could generate sympathy for those operating in a business context, but might also produce an insistence on adherence to prevailing standards of business conduct. Preconceptions about specific corporations could affect both individual-business cases and businessbusiness disputes. A corporation's reputation, the popularity or social utility of the product a company manufactures, ${ }^{85}$ and the size of the business enterprise could all play a role in jury judgments. Exactly how such potential biasing factors are translated into liability and damage determinations awaits empirical investigation.

For all these reasons, it is useful to know whether jurors in corporate cases bring to their task characteristic predispositions and attitudes about business that influence their evaluation of liability and damages. Research assessing juror attitudes toward business cases is limited; but we can gain some insights about the likely attitudes of jurors by combining the available work on juries with survey research examining public opinion about businesses and business wrongdoing.

\section{A. Attitudes Toward White Collar, Corporate, and Business Wrongdoing}

The results of public opinion surveys suggest that the American public has ambivalent reactions to business. Its expressions of support for business are greatest when given at a general, abstract level. For example, 86 percent of respondents in one contemporary survey indicated that they held favorable views toward business. In their evaluations of major institutions in society, these respondents ranked business and industry second only to the churches,

83. 3 L. Sand, J. Siffert, S. Reiss, J. Sexton \& J. Thrope, Modern Federal Jury Instructions, Civil, 72-2, instruction 72-1 (1988). The model instruction was based on two sources: the Fifth Circuit's pattern instruction No. 2B ("A corporation is entitled to the same fair trial at your hands as is a private individual. The law is no respecter of persons, and all persons, including corporations, stand equal before the law and are to be dealt with as equals in a court of justice"), and the Ninth Circuit's pattern instruction No. 12.12 ("The fact that a plaintiff or defendant is a corporation should not affect your decision. All persons are equal before the law, and corporations, whether large or small, are entitled to the same fair and conscientious consideration by you as any other person."). Id. at 72-2 to 72-3. As Richard Lempert has noted, it would be interesting to vary the presence or absence of such instructions in a mock-trial setting to determine whether and in what manner jurors are affected by such instructions. Personal communication with Richard Lempert (Oct. 29, 1988).

84. V. HANS \& N. VIDMAR, supra note 41, at 131-148. Jurors' sympathies and prejudices appear to affect their verdicts primarily when the facts of the case are close, and either conviction or acquittal could be justified by the evidence. H. Kalven \& H. ZeISel, supra note 42.

85. Consider the low regard for oil and tobacco companies documented by S. LiPSET \& W. Schneider, The Confidence Gap: Business, Labor, and Government 197, Fig. 6-2 (rev. ed. 1987). 
and above the press, educational institutions, and even the U.S. Supreme Court. ${ }^{86}$ In another survey, six out of ten respondents selected the free enterprise system as "the major reason for our higher standard of living" and "one of the major causes of United States greatness." 87 In surveys conducted in the 1980's, 58 percent agreed that "what's good for business is good for the average person." 88

Despite the public's overall approval of business, Lipset and Schneider have documented a decrease in general public support for big business and business leaders. ${ }^{89}$ Americans appear to place less confidence in business now than they did in earlier times. ${ }^{90}$ In a similar vein, Francis Cullen, William Maakestad, and Gray Cavender argue that the public has become increasingly willing to approve sanctions against the powerful, as a consequence of events of the 1970's and 1980's that undermined public confidence in major institutions and challenged the legitimacy of law and the social order. ${ }^{91}$

There is no evidence that the general public turns a blind or a kind eye to crimes that occur within business contexts. First of all, the public believes that business crime is a widespread problem. In a 1986 New York Times survey, respondents were asked, "There's been a lot of news recently about individuals and corporations committing white collar crimes to make a profit for themselves and their companies. How often do you think this happens in American business?" Fifty-six percent of the respondents thought that it happened "very often." 92 In another poll 55 percent of the respondents described most corporate executives as "not honest."93 Cullen and his colleagues ${ }^{94}$ discovered that their Illinois respondents believed the economic and moral costs of white collar crime surpassed the costs of street crime.

To determine whether the public is more tolerant of suite crime than of street crime, opinion surveys have compared people's judgments of the seriousness of white collar/business crimes and street crimes.95 This comparative approach, in line with other studies, ${ }^{96}$ reveals no evidence of

86. Roper \& Miller, Americans Take Stock of Business, 8 PUB. OPINION 12 (1985).

87. Id. at 13 .

88. Id. See also S. Lipset \& W. SCHNEIDER, supra note 85, at 285-89, for other survey results showing strong support for the free enterprise system.

89. S. Lipset \& W. Schneider, supra note 85, at 367-69.

90. It is interesting that in a capitalist democracy there is also evidence of general hostility toward the profit motive, and particularly toward individuals and companies who make big profits. See id. at 173-83 for a discussion of public disdain for profits and evidence that the public exaggerates business profit.

91. F. Cullen, W. Maakestad \& G. Cavender, supra note 61.

92. Opinion Roundup, 9 Pub. Opinion 21,22 (1986).

93. Id.

94. Cullen, Mathers, Clark \& Cullen, Public Support for Punishing White-Collar Crime: Blaming the Victim Revisited?, $11 \mathrm{~J}$. CRIM. JUST. 481,487 (1983).

95. Rossi, Waite, Bose \& Berk, The Seriousness of Crimes: Normative Structure and Individual Differences, 39 Ам. Soc'y Rev. 224 (1974); Wolfgang \& Figlio, Weighing Social Responsibility: How Perceptions Differ for Individual and Corporate Crimes, WharTon SCHOOL ECON. ANN. 32 (1985)

96. Cullen, Mathers, Clark \& Cullen, supra note 93; Grabosky, Braithwaite \& Wilson, The $M y t h$ of Community Toletance toward White-Collar Crime, 20 Australian and New Zealand J. Crim. 33 (1987); Roper \& Miller, supra note 86. 
leniency toward white collar and business criminals. To the contrary, the public frequently sees business crime as quite serious and deserving of punishment. Thus, considerable survey evidence indicates that while Americans strongly support business, they do not condone corporate misbehavior. ${ }^{97}$

General attitudes toward punishment may also be implicated in responses to corporate wrongdoing. In the criminal justice arena, individual attitudes are characteristically clustered around typically liberal "due process" or typically conservative "crime control" poles, with crime control advocates more likely to prefer swift and strong punishment. However, as Lee Hamilton has shown in another context, ${ }^{98}$ because desires to punish are linked to the personality characteristic of authoritarianism, high authoritarians may display less punitive responses to wrongdoing when it occurs in a hierarchically ordered environment such as a corporation. ${ }^{99}$ It is an interesting question for future research to clarify whether such urges to punish (previously studied primarily in terms of criminal sanctions) affect jurors' decisions about holding civil defendants liable for wrongdoing, or whether they drive up damage awards, or both.

What effect might this mix of attitudes have on juror judgments in business cases? Generalizing from jury selection research in the criminal context, ${ }^{100}$ one would have to say that very general attitudes toward business are unlikely to constitute strong predictors of jurors' judgments in particular cases. Typically the evidence, rather than extralegal or personal factors, drives juror decisionmaking. It is possible that more highly differentiated sets of attitudes toward the societal roles and responsibilities of businesses may affect jurors' evaluation of the evidence and the liability of specific corporations. The next two sections explore this possibility, taking up two specific dimensions of corporate and business responsibility, both pertaining to cases in which corporations and individuals face off in court. First is the most common charge against juries deciding business cases-that they operate with a deep pockets mentality. Next is a review of the evidence that

97. A good deal of the work on attitudes toward white collar crime has focused on the United States, but there is excellent work from both Australia and Great Britain showing similar patterns. See, e.g., M. Levi, Regulating Fraud: White-Collar Crime and the Criminal Process (1987), for an examination of British research, and Grabosky, Braithwaite \& Wilson, supra note 96, for a summary of Australian public opinion work.

98. Hamilton, Individual Differences in Ascriptions of Responsibility, Guilt, and Appropriate Punishment, in Psychology and the Law 239 (G. Bermant, C. Nemeth \& N. Vidmar eds. 1976).

99. See Kadish, Some Observations on the Use of Criminal Sanctions in Enforcing Economic Regulations, in White-Collar Crime: Offenses in Business, Politics, and the Professions 296 (G. Geis \& R. Meier eds. rev. ed. 1977). Kadish observed that political conservatives, who typically support rigorous punishment for ordinary offenders, seemed less supportive of such punishment for business offenders. Id. at 297. I am indebted to my colleague David Ermann for bringing this citation to my attention.

100. Hans \& Vidmar, Jury Selection, in The Psychology of the Courtroom 39 (N. Kerr \& R. Bray eds. 1982). This work is consistent with a larger body of psychological research on the attitudebehavior relationship, a longstanding topic of interest to social psychologists. 
there exists even today a strong tension between individual and corporate responsibility.

\section{B. The Deep Pockets Effect: Evidence of an Alternative Standard for Corporations?}

Perhaps the most frequently voiced criticism of juries in business cases is that juries unfairly consider the financial resources of corporate defendants in compensating individual plaintiffs. Rand Corporation researchers examined jury verdicts in Cook County, Illinois, during the 1960's and 1970's, and discovered that, in cases with plaintiffs who had serious personal injuries, corporate and governmental defendants were more likely to be found liable and to be required to pay larger damage awards than individual defendants. ${ }^{101}$ No such differences for the defendant's identity were observed in cases with less serious injuries. The results appeared to provide support for a deep pockets explanation of jury awards, in which jurors take into account the financial resources of the defendant when determining compensatory damages. ${ }^{102}$ A less pejorative way of describing such jury awards that depend on the relative resources of the parties is to say that jurors are balancing the equities of the situation. Rather than inflating awards against corporate defendants, juries may be discounting awards against individual defendants because of the perceived deleterious consequences of a large award. ${ }^{103}$

Juries may also be responding to other differences between corporations and individuals besides their financial resources. One theory about why people may treat the corporation distinctively focuses on the nonfinancial resource superiority of organizations over individuals. The typical corporation is organized around a rational structure and contains a number of individuals with specialized skills. On the basis of these characteristics, corporations may be assumed to possess greater rationality and better ability to anticipate the consequences of their endeavors than individuals. If corporations are better able to foresee the consequences of their actions, then they should be judged more severely for their violations. More severe punishment for intentional behavior is, of course, perfectly in line with the link between intentionality and culpability that characterizes both the criminal and the civil justice systems. ${ }^{104}$ The perception that corporations are more likely to foresee injuries could lead directly to greater presumptions of

101. A. Chin \& M. Peterson, Deep Pockets, Empty Pockets: Who Wins in Cook County Jury Trials 42, Table 4.4 (comparative liability), 43, Table 4.5 (median awards), and 45, Fig. 4.1 (expected median awards) (1985). Other potential explanations for this pattern exist.

102. Of course, juries are instructed to consider the defendant's financial resources in awarding punitive damages.

103. MacCoun draws on distributive justice research to propose several different hypotheses that might account for defendant identity effects, including pure need, severe need, equality, or equity/proportionality. R. MACCoun, supra note 41, at 34-36.

104. R. Epstein, C. Gregory \& H. Kalven, supra note 9, at 3-54; J. Kaplan \& R. Weisberg. Criminal law: Cases and Materials 131 -79 (1986); K. Shaver, The Attribution of Blame: CaUsality, ResponsibilitTy and Blameworthiness (1985). 
liability. Desires to sanction a corporation for intentional misbehavior could then drive up the damage awards. ${ }^{105}$ Sociologists and other scholars have demonstrated numerous instances in which corporations violate principles of rationality. ${ }^{106}$ Nevertheless, what would appear as an accidental act when committed by an individual may seem purposeful when a corporation engages in the act.

On the other hand, the fact that corporations typically consist of groups of people is likely to lessen assessments of responsibility for individuals within the group. A situation in which no single person can be identified as responsible may inhibit jurors and make them reluctant to pin blame. Individual members of a group are likely to benefit from the well-documented phenomenon of diffusion of responsibility within a group. ${ }^{107}$ A further contributor to perceptions of decreased responsibility is the fact that many members of the corporation may have been acting on orders from superiors, and this situation typically reduces judgments of individual culpability. ${ }^{108}$ Therefore, individuals within a corporation are likely to be held less culpable for wrongdoing.

However, for serious harms, a corporate group might be assigned greater responsibility than a similarly situated individual. In assigning responsibility for an extreme event, people tend to infer the existence of multiple necessary causes such as might be present in group efforts. A single actor may not be perceived as a sufficient cause for a major disaster. ${ }^{109}$ For example, in studies exploring why conspiracy theories of presidential assassinations are so popular, McCauley and Jacques discovered that groups are seen as more effective than individuals. 110 When extreme events occur, people appear to look for substantial causes. This could explain the pattern described above in the Chin and Peterson study of jury awards, where differences in jury verdicts

105. Stephen Daniels has discovered that punitive damage awards occur primarily in cases involving intentionally inflicted harms. It is also possible that perceptions of intentionality could lead to higher compensatory damage awards. Daniels, Punitive Damages: The Real Story, 72 A.B.A. J. 60,61 (Aug. 1986).

106. M. Ermann \& D. Lundman, Corporate Deviance (1982).

107. Darley \& Latane, Bystander Intervention in Emergencies: Diffusion of Responsibility, $8 \mathrm{~J}$ Personality \& Soc. Psychology 377 (1968); Wilder, Social Categorization: Implications for Creation and Reduction of Intergroup Bias, in 19 Advances in Experimental Soc. Psychology (L. Berkowitz ed. 1986).

108. H. Kelman \& V. Hamilton, Crimes of Obedience: Toward a Social Psycholocy of AUthority and Responsibility (1989).

109. In this context it is interesting to note that in both the Exxon Alaskan oil spill and the Bhopal disaster, specific individuals could have been viewed as responsible for the harm: the allegedly drunken captain of the Valdez, $c f$. Egan, Exxon Concedes It Can't Contain Most of Oil Spill, N.Y. Times, Mar. 30, 1989, at Al, col. 1, and a disgruntled employee at the Bhopal plant, $c f$. Labaton, Plaintiffs Faced Major Hurdles, N.Y. Times, Feb. 15, 1989, at D3, col. 1. My analysis suggests that attempts to blame single individuals for disasters of these magnitudes might have been unsuccessful. And this hypothesis is borne out as well in the recent outcome of Captain Hazelwood's criminal trial in Alaska. State v. Hazelwood (Alaska Super.) (Nos. 3AN-89-7217 Cr., 3-AN-89-7218), Mar. 23, 1989, appeal filed. Apr. 13, 1990.

110. McCauley \& Jacques, The Popularily of Conspiracy Theories of Presidential Assassinations, $37 \mathrm{~J}$. Personality \& Soc. Psychology 637 (1979); see also Latane, The Psychology of Social Impact, 36 Am. Psychologist 343 (1981). 
between individuals and governmental and business groups emerged only when the plaintiffs were severely injured. ${ }^{111}$

To explore some of these issues about judgments of corporate versus individual responsibility, David Ermann and I conducted an experiment in which we varied the identity of the defendant. ${ }^{112}$ We altered the actor in an otherwise identical scenario involving harm to workers. Half the respondents learned that a Mr. Jones had hired five workers to clear some recently purchased land, while the remainder were told that the Jones Corporation had done so. After a few hours of work, the workers began feeling ill. They continued working after notifying Jones, but then experienced more severe symptoms. Ultimately, all the workers required medical care, and three of them needed hospitalization. Analysis of the debris on the land revealed the presence of a highly toxic chemical. The workers ultimately sued Jones for damages relating to the incident, and the local prosecutor brought criminal charges against Jones. After reading either the "Mr. Jones" or the "Jones Corporation" version of the scenario, the respondents acted as mock jurors to decide Jones' civil and criminal responsibility.

We found striking differences in the way that people perceived and responded to corporate wrongdoing. The respondents believed that the corporation was more likely to have known beforehand that the workers might be harmed. Despite the identical actions of $\mathrm{Mr}$. Jones and the Jones Corporation, the respondents saw the corporation as more reckless, more morally wrong, and more blameworthy. They were more likely to judge that the Jones Corporation was civilly and criminally culpable. Consistent with the Chin and Peterson archival analyses, ${ }^{13}$ the amount awarded to the plaintiffs suing the Jones Corporation was almost twice the amount awarded to plaintiffs suing Mr. Jones. The results of the experiment indicated that people have a distinctive view of corporate as opposed to individual wrongdoing.

To explore why our respondents had differential reactions to the individual and the corporation, we analyzed the subjects' responses using multiple-regression techniques. We discovered that judgments of civil and criminal liability and awards were most strongly related to beliefs about intentionality and recklessness in both the $\mathrm{Mr}$. Jones and the Jones Corporation conditions. Surprisingly, the awards of the plaintiffs suing the Jones Corporation were not significantly related to judgments of financial resources (measured in our study by respondents' estimates of the likelihood of insurance and bankruptcy), which would have been predicted by a deep pockets explanation.

The overall pattern of results led us to hypothesize that people employed a different, and higher, standard in evaluating corporate wrongdoing. We speculated that the imposition of a higher standard could be due to our

111. A. Chin \& M. Peterson, supra note 101

112. Hans \& Ermann, Responses to Corporate Versus Individual Wrongdoing, 13 LAW \& Hum. BEHAV. $151(1989)$

113. A. Chin \& M. Peterson, supra note 101 
respondents' perceptions of the nonfinancial resource superiority of corporations. However, the design of our study did not permit us to rule out an alternative explanation, namely that negative stereotypes of corporations predisposed our respondents to take a relatively harsh view of corporate behavior. Future work will attempt to tease out these different explanations for the observed differentiation of individual and corporate responsibility. ${ }^{114}$

\section{The Tension between Corporate and Individual Responsibility: The Tobacco Company Cases}

Signs of a long-term shift toward greater collective and corporate responsibility 115 and evidence that the public desires punishment for business crime and is willing to hold corporations to high standards might suggest that juries today insist on corporate and business responsibility under most if not all circumstances. But that is telling only part of the story. There are considerable tensions and subtleties in the views juries take in cases in which corporate responsibility and individual responsibility are counterposed. Indeed, substantial portions of the citizenry actively resist attributing responsibility to corporate and business entities under many circumstances.

Many members of the public continue to adhere strongly to the ethic of individual responsibility. One of the most compelling illustrations of this tendency is given by David Engel's sensitive portrait of a small rural Illinois community, the majority of whose members remained hostile to the use of lawsuits for personal injury compensation.116 Plaintiffs were seen as troublemakers. Transforming a personal injury into a claim against another individual or a business was viewed as an attempt to escape responsibility for one's own actions. The community members' lay views reflected the doctrines of contributory negligence and assumption of risk, both of which focus on what the victim could have done to prevent injury.

Such preferences for individual responsibility are not the sole province of small rural districts, but may be found in larger communities as well. People differ substantially in the extent to which they hold individuals or external conditions responsible for events. ${ }^{117}$ National Jury Project researchers have developed a continuum to describe prospective jurors' views, from the "personal responsibility" perspective, where complete responsibility is attributed to individuals for adversity, to the "social responsibility" perspective, where more credit is given to environmental and social factors. Prospective jurors with a personal responsibility perspective are more reluctant than others to hold groups such as businesses or municipalities

114. Such work has begun only recently. See V. HaNs, supra note 68 ; R. MaCCoun, supra note 68 .

115. See supra text at $178-80$.

116. Engel, Law, Time, and Community, 21 Law \& Soc'y Rev. 605 (1987); Engel, The Oven Bird's Song: Insiders, Outsiders, and Personal Injuries in an American Community, 18 Law \& Soc'y Rev. 551 (1984).

117. National Jury Project, Jurywork: Systematic Techniques (2d ed. 1987). See also Vidmar \& Schuller, Individual Differences and the Pursuit of Legal Rights: A Preliminary Inquiry, 11 Law \& Hum. BEHAV. 299 (1987), documenting substantial differences among people in "claims consciousness," the extent to which they will perceive and act upon claims. 
responsible for harms, particularly when the plaintiff contributes in even a minor way to the harm. ${ }^{118}$

Tensions exist between individual and corporate responsibility. Consider the following question: What is the moral and financial responsibility of large companies that market an admittedly dangerous product (with little if any socially redeeming value) directly linked to thousands of deaths and severe injuries per year? If asked this question in the abstract in the 1980's, one might be tempted to reply that the companies' culpability is obvious. Yet, when confronted with the concrete situation of the tobacco companies' marketing and sale of cigarettes, most juries and the majority of the public have been willing to absolve the companies from responsibility for the physical harms caused by smoking. Indeed, the stunning litigation successes of the tobacco companies, and interviews with the jurors who decided those cases, illustrate that there are limits to business responsibility. Before 1988, the tobacco companies prevailed in every one of some 300 lawsuits against them. Interviews of jurors in two past trials that ended in victories for the tobacco companies showed that jurors felt reluctant to hold tobacco companies liable when smokers knew-or should have known-of the harm.119 As one juror said, "People are responsible for their own smoking, whether tobacco companies advertise or not. A person with any common sense whatsoever is going to recognize that smoking is bad for you. I don't believe the companies can be held responsible . . . ."120

The Cipollone case, decided in 1988, was the first case in which a jury awarded money to a plaintiff against a tobacco company for smoking injuries. ${ }^{121}$ Yet even in this case, the jury awarded money not to the estate of the smoker, Rose Cipollone, who was judged to be 80 percent responsible for her own injuries and cancer death, but rather to her widowed husband. And in a complex opinion, the Third Circuit Court of Appeals recently set aside the verdict and remanded the case for retrial. ${ }^{122}$

Within two weeks of the Cipollone jury verdict, I surveyed a convenience sample of 105 Delaware adults about their views of the case. ${ }^{123}$ We asked our respondents whether they had heard "about the New Jersey jury verdict a few weeks ago in a case against a tobacco company." Three-quarters of our respondents ( 73 percent) had heard about the case, but most said they had

118. National Jury Project, supra note 117 , at $\$ 13.02[1]$.

119. Gidmark, The Tobacco Juries-An In-Depth Study, 10 TRIAL DiPL. J. 18 (1987).

120. Id. at 26.

121. Cipollone v. Liggett Group, Inc., U.S. District Court, No. 83-2864 (D.N.J. 1988). The jury found that the cigarette company was responsible for pre-1966 actions, including failure to warn of tobacco's dangers and breaching express warranties. For interesting discussions of the case and its implications, see Blum, Tobacco Litigation: Cipollone and Its Progeny, 11 Nat'l. L.J. 20 (Dec. 26, 1988-Jan. 2, 1989); Daynard \& Morin, The Cipollone Documents: Following the Paper Trail to Tobacco Industry Liability, 24 Trial 50 (1988).

122. Cippolone v. Liggett Group, Inc., 893 F.2d 541 (3d Cir. 1990).

123. We sampled adults who were at Market Street Mall in downtown Wilmington, Delaware, at lunchtime. It was a nonrepresentative sample; although the sample and 1980 county census figures for gender and race were almost the same, the sample was more highly educated and younger than the census figures. 
heard only a little about it. Nevertheless, 58 percent of the sample was able to correctly identify the plaintiff as the party who won the case. Just one person incorrectly identified the tobacco company as the winner of the lawsuit.

Respondents were also asked if they remembered the amount that the jury had awarded the Cipollone plaintiff. Just one-third gave an award amount, with only eight respondents correctly recalling that the jury had awarded the plaintiff a total of $\$ 400,000 .^{124}$ Those giving incorrect awards overestimated the amount by a two-to-one margin. ${ }^{125}$

We then told them about the facts of the case and the jury's actual verdict, and asked several questions about their reaction to the case. Reactions to the verdict were split, with 39 percent supporting and 45 percent opposing the verdict. Most of our respondents felt that the $\$ 400,000$ award was too high. Although the Cipollone plaintiffs introduced internal industry documents to support their contention that the tobacco companies had engaged in a conspiracy to mislead the public about the dangers of smoking, the jury dismissed the conspiracy claim. ${ }^{26}$ Our respondents were similarly unlikely to perceive the tobacco companies as being involved in a conspiracy.

Analysis of the respondents' views on smokers and tobacco companies indicated that they held strong views of individual responsibility for smoking. Smokers were seen as fully informed about the negative consequences of indulging in their vice; even nicotine addiction was perceived as no excuse for engaging in personally injurious behavior. In the eyes of these respondents, the responsibility for smoking rested squarely on the shoulders of the smokers themselves. For example, 95 percent agreed that "with all the warnings today, if cigarette smokers die of cancer, it's their own fault." In key ways, respondents absolved the tobacco companies for marketing a harmful product. Most people saw the tobacco companies as meeting their obligation to inform consumers about health risks, and saw present regulatory laws as generally adequate.

Another strong theme was the belief that many lawsuits against companies were illegitimate. Eight out of ten respondents believed that there are far too many frivolous lawsuits today; six out of ten saw the threat of lawsuits as interfering with the development of new and useful products. And plaintiffs

124. The median estimated award of $\$ 500,000$ was quite close to the actual award, but the mean award was $\$ 16.2$ million, reflecting the extreme overestimates of the award by some of our respondents.

125. The scanty and faulty recollections are interesting in terms of what Galanter, following Mnookin and Kornhauser's classic article, Bargaining in the Shadow of the Law: The Case of Divorce, 88 Yale L.J. 950 (1979), calls "jury shadows." Galanter, Jury Shadows: Reflections on the Civil Jury and the Litigation Explosion, in M. Arnold, B. BabbitT, M. Galanter, J. Guinther \& D. Higgenbotham, The AMERICAN Civit. JuRY 15 (1987). The results of this admittedly nonrepresentative survey of recollections hint that people are likely to remember who won a case but little else. Few of the other details about the case appear to survive even a couple of weeks.

126. Daynard \& Morin, supra note 121, at 54; Singer, They Didn't Really Blame the Cigarette Makers, AM. Law., Sept. 1988, at 31. To the majority of jurors, the company's actions "just seemed like business as usual, the kind of thing you'd expect from any major industry." Id. at 35 . 
in tobacco company lawsuits were perceived as "just trying to blame someone else for their problems." Perceptions that lawsuits were often illegitimate were strongly linked to opposition to the Cipollone verdict.

This evidence of public hostility toward plaintiffs who sue the tobacco companies converges in a remarkable way with posttrial interviews of the Cipollone jurors. ${ }^{127}$ The interviews painted a picture of a divided jury, the majority of which held strong opinions that Rose Cipollone was largely responsible for her own cancer death and deserved no compensation from the cigarette manufacturers. ${ }^{128}$ The defense strategy of demonstrating that Rose Cipollone was highly aware of the dangers of smoking convinced at least four jurors that the cigarette company should not be held responsible for her injury. 129 However, the two other jurors were more sympathetic to the plaintiffs. As one of the defense-oriented jurors stated about the others, "if they had their whole say, [they] would have found [the tobacco companies] guilty of anything and everything." 130 The jury agreed to compromise upon a modest damage award to Rose Cipollone's husband. ${ }^{131}$ The Cipollone jurors reflected some of the same tensions and ambivalence that are prevalent in public reactions toward holding corporations responsible for individual behavior. ${ }^{132}$

Thus, while scholars point to evidence indicating that the public is now predisposed to holding businesses and other group entities liable for injuries, there are manifestations of a contrary ethic of personal responsibility. This widely supported social norm has no doubt contributed to the success of various efforts to limit corporate and business liability during the most recent wave of tort reform. In the 1980's, tort reformers have called for new limitations on the liability of collective entities; insurance and business groups have successfully lobbied state legislatures to enact laws limiting business liability and damages. ${ }^{133}$

127. Singer, supra note 126. One caveat about relying on this article for a complete picture of the Cipollone jury is that only the four pro-defense jurors consented to be interviewed; the two proplaintiff jurors refused to be interviewed by Singer. A brief report of several juror interviews is given in 3 Jurors Now Say Tobacco Companies Should Not Pay, The News \& Observer (Raleigh, N.C.), Sept. 4, 1988 , at $4 \mathrm{~A}$.

128. Singer, supra note 126.

129. Id. at 32 .

130. Id.

131. Id. at 31 .

132. The survey findings and juror interviews indicate that when individuals are perceived as knowledgeable about and able to control their own injuries, judgments of corporate and business responsibility are less likely. Therefore, if they were able to overcome the problems inherent in proving harm from second-hand smoke, "passive" smokers should be more likely to prevail against the tobacco companies than those who willingly light up.

133. U.S. Attorney General's Report, Tort Policy Working Group (1986); Am. Bar Ass'n, Report of the Action Commission to Improve the Tort Liability System (1987). 


\section{ConCLUSION}

Historical and archival studies show an increasing business presence in the courts. Past research on jury decisionmaking gives us reason to be optimistic that lay juries are up to the task of comprehending and assessing liability in the vast majority of cases involving businesses and corporations. The jury has considerable strength as a factfinder. By pooling the collective wisdom of six or twelve citizens in group deliberation, the jury reduces the chance that factual misunderstandings will lead to faulty verdicts. That is an important advantage, because judges and jurors alike may have difficulty understanding the scientific, technical, economic, and statistical evidence characteristic of many business cases. As investigators continue to examine the influence of such testimony on juries, they should also study how any problems of evidentiary understanding can be ameliorated. Some alterations in traditional jury trials-permitting jurors to ask questions of expert witnesses, or dividing issues to be considered by juries in complex trials, to name just two-may be necessary to ensure the fullest possible comprehension of the central facts in complicated cases involving business wrongdoing.

Research indicates that juries might well take a distinctive approach to evaluating corporate and business wrongdoing, holding corporations and individuals to different standards. It is not yet clear under what circumstances this will occur, nor why juries treat businesses differently. Possibly, juries are simply reflecting current social norms of increased corporate responsibility for wrongdoing. Alternatively, their judgments could reveal anticorporate bias. Yet even in cases involving some of the most negatively evaluated businesses around-the tobacco companies-juries show remarkable restraint in judging corporate culpability. One task for researchers will be to explore what facilitates or impedes perceptions of business responsibility. Do the size, reputation, and financial status of the corporation affect judgments of liability and damages? Gaining knowledge of the circumstances under which people will and will not hold corporate and business entities liable is a critical step toward understanding how juries respond to cases involving business and corporate wrongdoing. It will also be of interest to learn what life experiences or demographic characteristics contribute to expansive or restricted views of the responsibility of corporations.

In developing a comprehensive picture of jury decisionmaking in business cases, an important step is fuller documentation of the kinds of cases and range of issues and evidence juries most frequently confront. In discussing the evaluation of corporate responsibility, this article has often counterposed the individual and the corporation. Future work will have to differentiate more systematically than has been possible here cases in which individuals sue businesses from those in which businesses sue one another. This study has barely touched upon some of the fascinating issues that arise in assessing the 
responsibility of individuals within businesses and corporations. ${ }^{134}$ For example, under what circumstances will jurors judge corporate directors responsible for harms caused by a subordinate? Do the perceptions of jurors and the lay public converge with legal rules about the responsibility of corporate actors within organizations?

In closing, it is important to note the highly charged and partisan context in which jury competence in business cases is evaluated and judged. Some people have argued that the intricacies of modern business disputes render them unfit for trial by jury. These critics would probably concede that the criminal jury continues to serve an important function in contemporary society as a protector of individual liberty, but would contend that the civil jury, particularly in complicated business trials, has outlived its utility. Legally trained judges and scientific experts might be better able to comprehend and decide the affairs of business. ${ }^{135}$

Yet juries in business cases play an important political role, one that could be considered just as significant as the jury's function in the protection of individual liberty in criminal trials. ${ }^{136}$ Juries deciding business cases are in a position to reflect in their verdicts contemporary norms about appropriate business standards and responsibilities. Ultimately, albeit imperfectly, jury verdicts help to regulate the conduct of business and corporate entities in our society. As Lempert notes, "complex cases-such as large-scale antitrust litigation-are some of the most 'political' cases that the system hears. Vast sums of money are involved, and the structure of the nation's largest companies may be at issue. The power of businesses vis-a-vis consumers is inescapably implicated."'137 It is understandable that there might be resistance on the part of businesses and corporations to the public control inherent in the institution of the jury, and that others might strenuously attempt to counteract this resistance. One consequence of this state of affairs is that research findings about the jury in business cases may be swiftly incorporated into partisan arguments for and against the jury. For example, work that aims to point out problem areas and to assist jury factfinding could be seized upon as evidence that juries are incompetent to decide such cases by those who prefer to sidestep popular control in the form of the jury. Balanced and objective presentations of research on the jury's evaluation of business cases are thus imperative. Those of us who study the jury in such cases must pay particular attention to the potential uses to which our research might be put. ${ }^{138}$

134. See 1 K. Brickey, Corporate Criminal Liability 99-150 (1984); R. Hamilton, Cases and Materials on Corporations 378-492 (3d ed. 1986).

135. See, e.g., Drazan, supra note 1.

136. See, e.g. Lempert, supra note 38 , at $80-84$. Lempert maintains that civil jury decisionmaking promotes important social values.

137. Id. at 84 .

138. See Daniels, The Question of Jury Competence and the Politics of Civil Justice Reform: Symbols, Rhetoric, and Agenda-Building, LaW \& Contemp. Probs., Autumn 1989, at 269. 
